\title{
ENVIRONMENTAL SENSITIVITY INDEX MAPPING OF LAGOS SHORELINES
}

\section{J.A. OYEDEPO ${ }^{1^{*}}$ C.O. ADEOFUN ${ }^{2}$}

Received: 29/11/10

Accepted: 04/07/11

\author{
${ }^{1}$ Research and Development Centre, University of Agriculture \\ 110001 Abeokuta, Nigeria \\ ${ }^{2}$ Department of Environmental management and Toxicology \\ University of Agriculture, 110001 Abeokuta, Nigeria
}

*to whom all correspondence should be addressed: e-mail: johnoyedepo@yahoo.com

\begin{abstract}
Environmental Sensitivity Index (ESI) mapping of Atlas Cove, Lagos, Nigeria was carried out with the objective of producing an Environmental Analysis Index map of the shorelines. The study integrated methodologies developed by National Oceanic and Atmospheric Administration (NOAA) and Nigerian Oil Producing Trade Sector (OPTS) for the study. The result of the assessment was validated by comparison with the ESI standads in Nigeria. 9 ESI types were found in the area namely; ESI types 1b, 2a, 2b 3a, 4a, 6b, 9b, 9c, and 10a. Animal biodiversities such as shorebirds (Tringaly poleucos and Charadrinning marginatus), sea turtles (Dermocellys spp) and white crabs (Occipoda africana) were more prominent on the western shores. Spearman's Correlation coefficient ( $r$ ) value of -0.6 was obtained for the association between number of socioeconomic features and biological species along the shores. This shows that a cause and effect exists between biological productivity and anthropogenic activities along the shorelines. The study ranked Mangrove swamps, creeks and fresh water swamp highest with ESI values of 10a. Margalef's index also shows that the same areas are the most sensitive with respect to species richness. The database developed from the study provides baseline information on the biophysical and socio-cultural condition of the environment and can serve as good decision support system for coastal managers.
\end{abstract}

KEYWORDS: ESI, Oil spill, Geographic Information Systems, Atlas cove, Nigeria.

\section{INTRODUCTION}

Environmental Sensitivity Index (ESI) mapping of Atlas Cove, Lagos, Nigeria was carried out with the objective of producing an Environmental Analysis Index map of the shorelines.

Sensitivity levels in this coastal environment were investigated to produce crucial information that would be useful for oil spill risk management of the area. This was necessitated by the fact that the of Atlas cove coastal environment in Lagos, has being undergoing progressive degradation from pipeline spills since the construction of the 64 million litre Nigerian National Petroleum Corporation (NNPC) oil depot in 1981. Oil pollution resulting from faulty petroleum facilities in the area has been so unremitting that repeated loss of lives and ecological devastation has been recorded. In addition, this environment and the adjoining sea fall within Oil Prospecting License blocks (OPL306, OPL311 and OPL 454). The implication of this is that the environment is vulnerable to both inland and off shore oil spill disasters.

Since environmental/ecological degradation from oil spill results in gradual erosion of biodiversity pools and species; which incidentally forms the basis for the survival of the human species, prevention of this kind of disaster through rapid and precise response action is not negotiable Fabiyi (2002). Meanwhile, comprehensive information on the sensitivity levels of each category of a susceptible environment is an important requirement for effective oil spill disaster management. Regrettably, the ESI documents that could support the development of good and robust oil spill contingency plans for the study area are not available. 
In Nigeria, ESI mapping began (Gundlach et al., 1981) as attempts by oil and gas operators to characterise the environment in their respective areas of operation by providing detailed and consistent source of information as a critical tool in oil spill response. But since oil mining and exploratory activities have been confined to the coastal zones of Niger delta (southern) region of Nigeria, no functional provision on oil spill contingency was made for other coastal areas outside the Niger delta region. Even though, mining activities is yet to commence here; the sea below the shorelines of Lagos is part of the Nigerian Oil Prospecting Licence (OPL) blocks (Egberongbe et al., 2006), as such Lagos shorelines are equally highly vulnerable to marine oil spill as those of the Niger delta region.

Although nuances exist between versions of sensitivity maps from zone to zone, the basic principles of the mapping have remained constant. This paper is a Nigerian example of ESI calculation. The paper adopted a modified Oil Producing Trade Sector protocol (OPTS, 2001) and National Oceanic Atmospheric Administration (NOAA, 1996) methodology respectively for ESI mapping of the study area. The methodology derived from the integration of the two techniques was designed to correspond to the available data at the time of the project. A new technique for validating shoreline sensitivity was added in Margalef's Species richness computation.

\section{METHODOLOGY}

\section{Study area}

The area is geographically described by latitudes $6^{\circ} 22^{\prime} 33^{\prime \prime}$ and $6^{\circ} 26^{\prime} 39^{\prime \prime}$ and by longitudes $3^{0} 32^{\prime}$ 00 and $3^{\circ} 45^{\prime} 00$. The area lie south west of Lagos city; overlooks the Bight of Benin (Atlantic Ocean) and is enmeshed with a net work of tortuous creeks and other water bodies. It has a variety of shore types ranging from marine to fine grained sand beaches is present. The fact that the area is part of the Oil Prospecting Licence (OPL) blocks and the presence of the 64 million litre Nigerian National Petroleum Company (NNPC) depot with series of oil pipelines/flow stations makes it highly vulnerable to risk of oil spill.

\section{Preliminary data}

Basic data sets include topographic map of Lagos, Oil facility map, a high resolution satellite remote sensing image (Ikonos acquired for year 2005) and Standard ESI validation table.

The Primary spatial data which include: a count of plant and animal Species count, soil/substrate and socioeconomic features were acquired during field work.

\section{Methods}

The Topographical and NNPC facility map were digitised at scale of 1:20000. An overlay of the two digitised map was performed to produce the Digital Base Map (DBM) of the area. This was updated with an Ikonos image acquired for December 2005. Field site logistic plan was then developed to determine among other things; requirement and date for field work, types of primary data to be collected, location of data collection and data size.

Stations were created at interval of 400 meters along the entire coastline on the updated base map and in each of the stations; in-situ data such as substrate types, shore slope, exposure to wave energy, number of flora and fauna Species present and socio-economic features present were collected. Geographical coordinates of all features and points of interest were taken with the aid of a hand-held GPS device. Figure 2 is a schema of the rapid shoreline assessment of the study area.

The in-situ data gathered were used to build up a relational database for the shorelines on the updated Digital Base Map (UDBM) to derive the Level 1 GIS map (L1GM) which, became modified into the Initial ESI map after incorporating biological and socio-economic feature as point symbols on the map.

Results of rapid assessment from (field notes and observations) along the shorelines were compared with the standard ESI look-up table prepared for Nigerian shorelines by the OPTS for validation. The shore types were classified into sensitivity ranks on a scale of 1 to 10 based on the original index of Gundlach and Hayes (1978) for Nigeria. The shorelines were later colour coded using ArcView 3.2 colour palette customisations. 


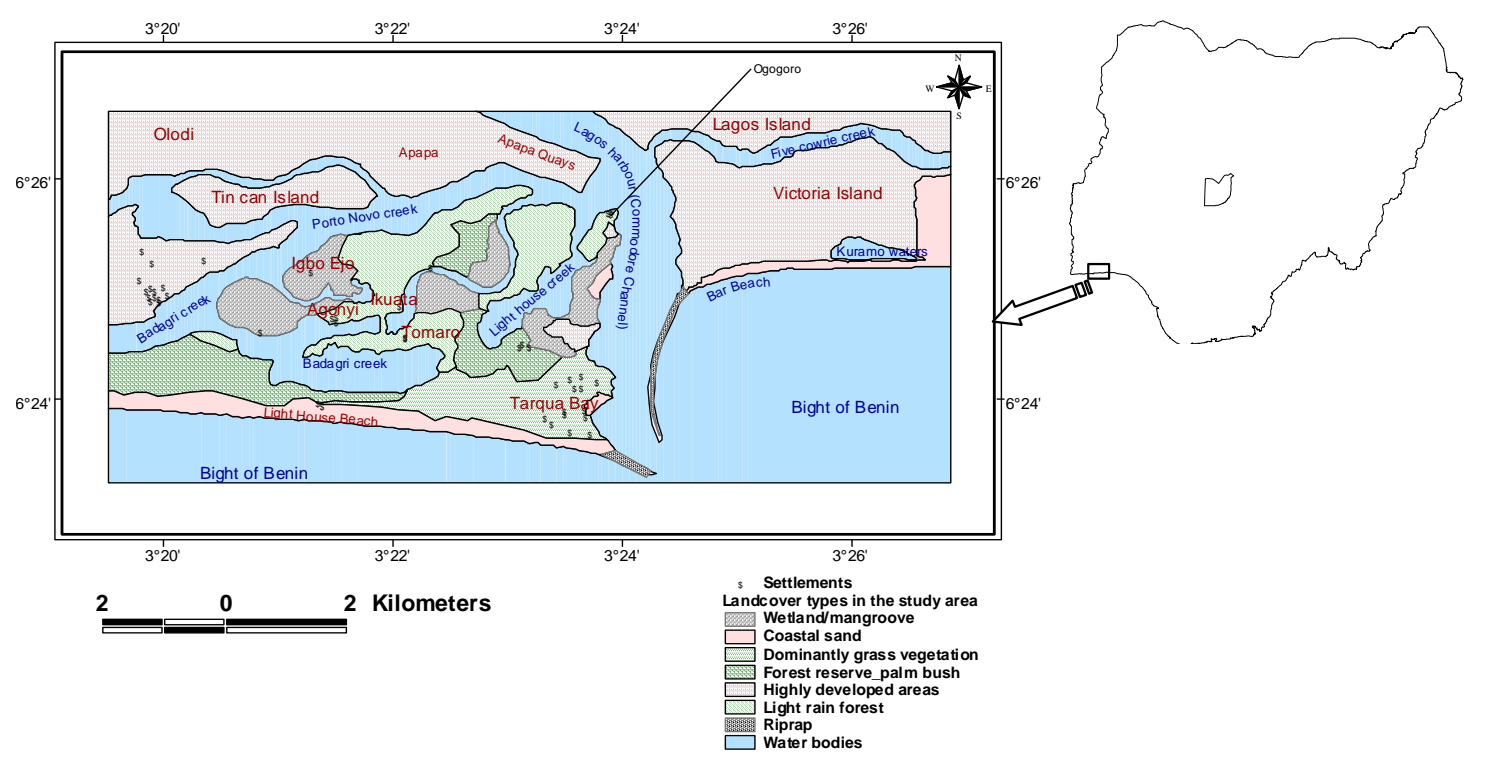

Figure 1. Map of the study area

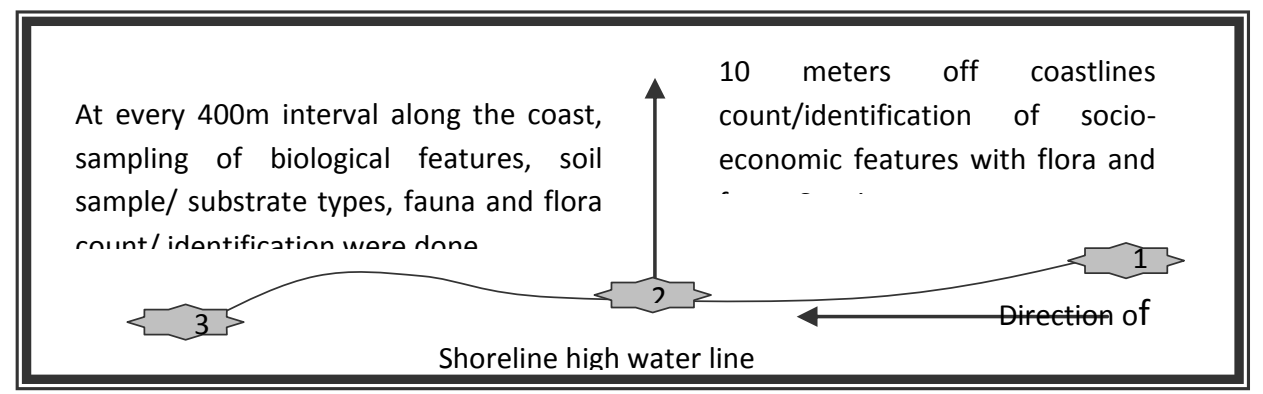

Figure 2. Rapid shoreline assessments plan

\section{Statistical data analysis}

The relationship between shoreline biological productivity and human influence through the number of socio-economic feature was measured using Spearman's rank correlation thus:

$$
r=1-\frac{6 \sum_{i=1}^{n} d_{i}^{2}}{n\left(n^{2}-1\right)}
$$

where $n$ is the number of observation and $d$ is the difference between the ranked variables.

\section{Rules for Sensitivity Determination}

Although, there is yet to be a unified yardstick for shoreline categorisation in Nigeria, the Oil Producing Trade Sector (OPTS) in Nigeria have adopted some rules which have been adopted in this study for determining the sensitivity rank of particular shorelines. Table 1 for instance is the standard ESI validation table with which to compare the results of rapid assessment along the shorelines in Nigeria what qualifies a shoreline as an ESI type is tabled out clearly. 
Table 1. Standard ESI validation table for shorelines

\begin{tabular}{|c|c|c|c|c|}
\hline ESI & Shore Type & Dominant Sediment type and slope & Slope & Exposure \\
\hline $1 a$ & $\begin{array}{l}\text { Exposed rocky shores or } \\
\text { banks }\end{array}$ & $\begin{array}{l}\text { Rocky }=\text { boulders }(>256 \mathrm{~mm}) \\
\text { Banks }=\text { marked by scarping, clays and muds } \\
(<0.625 \mathrm{~mm}) \text { are common }\end{array}$ & Moderate-High & Moderate-High \\
\hline $1 b$ & $\begin{array}{l}\text { Exposed sea walls and solid } \\
\text { man-made structures }\end{array}$ & $\begin{array}{l}\text { Vary from Boulders and cobbles (> } 64 \mathrm{~mm}) \text { to } \\
\text { sand bags, solid concrete, sheet pile or wood }\end{array}$ & Moderate-High & Moderate-High \\
\hline $2 a$ & Unvegetated/Eroding bank & Silt and clay $(<0.0625 \mathrm{~mm})$ & Very low slope & Moderate \\
\hline $2 b$ & Exposed wave-cut platform & Bedrock or boulders (> 256 mm) & $\begin{array}{l}\text { Low slope backed by bluff or } \\
\text { cliff }\end{array}$ & Moderate-High \\
\hline $2 \mathrm{c}$ & Rocky shoals, bedrock ledges & Bedrock or boulders (> $256 \mathrm{~mm}$ ) & Low slope & Moderate-High \\
\hline $3 a$ & Fine sand beach & Fine sand $(0.0625-2.0 \mathrm{~mm})$ & Low slope, $\left(<5^{\circ}\right)$ & Low-High \\
\hline $3 b$ & Scarps or steep slope in sand & Sand $=0.0625-2.0 \mathrm{~mm}$ & Marked by scarp or steep slope & Moderate-High \\
\hline $4 a$ & Medium to coarse sand beach & Grain size $=0.25-2.0 \mathrm{~mm}$ & Low to moderate & Moderate-High \\
\hline 5 & $\begin{array}{l}\text { Mixed sand and gravel beach, } \\
\text { bar or bank }\end{array}$ & Grain size $=1-64 \mathrm{~mm}$ & Low to moderate slope $\left(8-15^{\circ}\right)$ & Moderate-High \\
\hline $6 a$ & Gravel beach or bar & Grain size $<2 \mathrm{~mm}$, Moderate & Steep slope $\left(10-20^{\circ}\right)$ & Moderate-High \\
\hline $6 b$ & Riprap & Boulders (>256 mm) & Moderate to steep slope $\left(>20^{\circ}\right)$ & Moderate-High \\
\hline 7 & Exposed tidal flat & Coarse sand - mud $(<2 \mathrm{~mm})$ & Low slope $\left(3^{\circ}\right)$ & Low - moderate \\
\hline $8 a$ & Vegetated steeply sloping bluff & Soils (sand - mud) $(<1 \mathrm{~mm})$, boulders $(>256 \mathrm{~mm})$ & Moderate to steep slope $\left(>15^{\circ}\right)$ & Low \\
\hline $8 b$ & Sheltered Riprap & Boulders $(>256 \mathrm{~mm})$ & Moderate to steep slope $\left(>20^{\circ}\right)$ & Low \\
\hline $8 c$ & Sheltered rocky shore or scarp & Bed rock or boulders (>256mm) & Moderate to steep slope $\left(>15^{\circ}\right)$ & Low \\
\hline $9 a$ & $\begin{array}{l}\text { Sheltered tidal flat or sand } \\
\text { mud }\end{array}$ & Medium sand-mud $(<0.5 \mathrm{~mm})$ & Low slope $\left(3^{0}\right)$ & Low \\
\hline $9 b$ & Vegetated low bank & Soils [sand to $\operatorname{mud}(1 \mathrm{~mm})]$ & Low to moderate slope $\left(20^{\circ}\right)$ & Low \\
\hline $10 a$ & Mangrove Nympa palm & Mud $(0.625 \mathrm{~mm})$ Vegetation will indicate shore & Low slope $\left(3^{\circ}\right)$ & Low \\
\hline $10 \mathrm{~b}$ & Fresh water swamp & type & Low slope $\left(3^{\circ}\right)$ & Low \\
\hline 10c & Marsh & & Low slope $\left(3^{\circ}\right)$ & Low \\
\hline
\end{tabular}

Source: OPTS (2001)

In this paper, additional method of sensitivity indexing with respect to biodiversity distribution was presented. Since, the two methodologies modified for the study played down on biodiversity inclusion in sensitivity calculation; by only adding them cosmetically to the final ESI maps. In this paper, the distributions of biological features encountered along the shorelines were used to ascribe sensitivity values to the shores according to their richness in biodiversity. This was done using Margalef's Species richness (Margalef, 1961) applied in this study as $D_{a}=S-1 / \log N$ Where $\mathrm{S}$ equals the number of Species and $\mathrm{N}$ equals total number of individuals sampled. The guidelines that describe rules for classifying particular shoreline sensitivity with respect to species richness can be summarized as shown in Table 2:

Table 2. Rules for assigning sensitivity values to interior habitats Based on Species Richness and Species Diversity

\begin{tabular}{lll}
\hline Score Range & Points to be Assigned & Remarks on Values \\
\hline If score is 0 & Assign No points & No Sensitivity \\
If score is $>0-0.5$ & Assign 1 points & Very Low Sensitivity \\
If score is $0.51-1.0$ & Assign 3 points & Very Low Sensitivity \\
If score is $1.1-2.0$ & Assign 4 points & Low Sensitivity \\
If score is $2.1-4.0$ & Assign 6 points & Moderate Sensitivity \\
If score is $4.1-6$ & Assign 7 points & High Sensitivity \\
If score is $6.1-8.0$ & Assign 8 points & High Sensitivity \\
If score is $8.0->10$ & Assign 10 points & Very High Sensitivity \\
\end{tabular}




\section{RESULTS}

Table 3 presents the observations along the shores of Atlas cove. It guides in understanding the potential behaviour of oil slick along shores and the ESI types each shoreline belongs.

From Lagos harbour to Tarqua bay and light house beaches, the grain sizes are finer $(0.0625$ $0.25 \mathrm{~mm}$ ) than those of the Bar beach and Kuramo beach in Victoria Island (medium sized grain $0.25-2.0 \mathrm{~mm})$. The creeks and the mangroves substrates however have the finest grain size $(0.0625 \mathrm{~mm})$. Along the west and east moles heavy quarried rocks were placed as shoreline fortification. This of course is the largest in terms of substrate size $(>256 \mathrm{~mm})$. With respect to shore slope and exposure to wave energy, the ranking is similar to sediment grain size; the deepest slope $(0.75 \%)$ and the highest exposure to sea wave energy were observed along the west and east moles where the substrate size are also largest while the flattest slope (10\%) also corresponds to the Light house and Tarqua Bay shores with the finest substrate size. This trend is typical of the geomorphology Nigerian coastlines (Gundlach et al., 2001; Nosakhare et al., 2004)

Information in table 3 revealed 9 ESI types in the study area; this is more explicit in table 4. 1b (Sea walls/solid man-made structures), 2a (Un-vegetated or Eroding bank), 2b (Exposed wave cut platform), 3a (Fine sand beaches), 4a (Medium to coarse sand beach), 6b (Riprap), 9b (Sheltered vegetated low banks), 9c (Huts along shorelines) and 10a (Mangrove/swamps).

Table 3. Physiographic characteristics of the shorelines in Atlas cove

\begin{tabular}{|c|c|c|c|c|}
\hline Shore location & $\begin{array}{c}\text { Dominant substrate type } \\
(\mathrm{mm})\end{array}$ & Shore description & Slope & $\begin{array}{l}\text { Exposure to } \\
\text { wave energy }\end{array}$ \\
\hline Victoria island (Kuramo) & Grain size $=0.25-2.0$ & Medium to coarse sandy beach & 0.15 & High \\
\hline Victoria island (bar beach) & Grain size $=0.25-2.0$ & Medium to coarse sandy beach & 0.15 & Very High \\
\hline Light house beach & Fine sand $=(0.0625-0.25)$ & Fine sandy beach & 0.10 & High \\
\hline Tarqua bay beach & Fine sand $=(0.0625-0.25)$ & Fine sandy beach & 0.10 & Moderate \\
\hline East mole v/l side & Boulders $(>256)$ & Rip rap & 0.75 & Very high \\
\hline East mole (Lagos harbour) & Boulders (> 256) & Rip rap & 0.75 & Very high \\
\hline West mole (Lag harbour) & Boulders (> 256) & Rip rap & 0.75 & Very high \\
\hline West mole (light house) & Boulders (> 256) & Rip rap & 0.75 & Very high \\
\hline Lagos harbour(V/I side) & Solid concretes & $\begin{array}{l}\text { Sea walls/solid man-made } \\
\text { structures }\end{array}$ & -- & Moderate \\
\hline Lagos harbour (Atlascove) & Fine sand $=(0.0625-0.25)$ & Fine sandy beach & 0.20 & Moderate \\
\hline Badagri creek (water) & Sand-mud $(<0.0625)$ & Brackish/fresh water swamp & -- & -- \\
\hline Light house creek & Sand-mud $(<0.0625)$ & Brackish/fresh water swamp & -- & -- \\
\hline Five cowry creek & Sand-mud $(<0.0625)$ & Brackish/fresh water swamp & -- & -- \\
\hline Porto-Novo creek & Sand-mud $(<0.0625)$ & Brackish/fresh water swamp & -- & -- \\
\hline Badagri creek fringes & Sandy loam Soil (0.0625-0.25) & Sheltered Veg low banks & 0.20 & Low \\
\hline Five cowry creek fringes & Sandy loam Soil (0.0625-0.25) & Sheltered Veg low banks & 0.20 & Low \\
\hline Porto-Novo creek & Sandy loam Soil (0.0625-0.25) & Sheltered Veg low banks & 0.20 & Low \\
\hline Light house fringe & Sandy loam Soil (0.0625-0.25) & Sheltered Veg low banks & 0.20 & Low \\
\hline $\begin{array}{l}\text { Ogogoro, Kuata, Tomaro, } \\
\text { Tarqua bay }\end{array}$ & Sandy loam Soil (0.0625-0.25) & Huts along shorelines & 0.20 & Low \\
\hline Mangrove (via Ogogoro) & Grain size $=0.25-2.0$ & Mangrove & 0.15 & Low \\
\hline Mangrove (Via NNPC) & Grain size $=0.25-2.0$ & Mangrove & 0.15 & Low \\
\hline Mangrove (Tarqua bay) & Grain size $=0.25-2.0$ & Mangrove & 0.15 & Low \\
\hline Mangrove ( L.H. cork) & Grain size $=0.25-2.0$ & Mangrove & 0.15 & Low \\
\hline Mangrove (Badagri crk) & Grain size $=0.25-2.0$ & Mangrove & 0.15 & Low \\
\hline Mangrove(Badagri crk) & Grain size $=0.25-2.0$ & Mangrove & 0.15 & Low \\
\hline Mangrove & Grain size $=0.25-2.0$ & Mangrove & 0.15 & Low \\
\hline \multirow[t]{2}{*}{ Igbo Ejo swamp } & Sand-mud $(<0.0625)$ & & -- & -- \\
\hline & \multicolumn{4}{|c|}{ Brackish water swamp } \\
\hline
\end{tabular}

Source: Adapted from Gundlach et al., (2001) 
Table 4. Shoreline by categories

\begin{tabular}{|c|c|c|c|c|}
\hline ESI & Shore types & Location & $\begin{array}{l}\text { Total length } \\
\quad(\mathrm{km})\end{array}$ & $\begin{array}{l}\text { Percentage } \\
\text { of entire } \\
\text { shoreline }\end{array}$ \\
\hline $1 \mathrm{~b}$ & $\begin{array}{l}\text { Sea walls/solid man- } \\
\text { made structures) }\end{array}$ & $\begin{array}{l}\text { Eastern side of Lagos harbour, Apapa quays, part of } \\
\text { five cowrie creek, Tin can island port and NNPC } \\
\text { Depot }\end{array}$ & 19.53 & 23.5 \\
\hline $2 a$ & $\begin{array}{l}\text { Un-vegetated or } \\
\text { Eroding bank }\end{array}$ & Bar-beach end of Victoria island. & 2.46 & 3.0 \\
\hline $2 b$ & Exposed wave cut & Badagri creek near Kuata village. & 0.056 & 0.1 \\
\hline $3 a$ & Fine sand beaches & $\begin{array}{l}\text { Tarqua bay light house and western side of Lagos } \\
\text { harbour }\end{array}$ & 12.28 & 14.8 \\
\hline $4 a$ & $\begin{array}{l}\text { Medium to coarse sand } \\
\text { beach }\end{array}$ & Kuramo end of Victoria Island beach & 1.79 & 2.2 \\
\hline $6 \mathrm{~b}$ & Riprap & West and Eastern Lagos harbour. & 8.74 & 10.5 \\
\hline $9 b$ & $\begin{array}{l}\text { Sheltered Vegetated low } \\
\text { banks }\end{array}$ & $\begin{array}{l}\text { Found along all creeks occurring along upper } \\
\text { reaches of creeks embayment. }\end{array}$ & 31.03 & 37.3 \\
\hline $9 c$ & $\begin{array}{l}\text { Huts or settlements } \\
\text { along shorelines }\end{array}$ & Ogogoro, Kuata and Tomaro villages. & 1.44 & 1.7 \\
\hline $10 \mathrm{a}$ & Mangroves/swamps & & 5.77 & 6.9 \\
\hline
\end{tabular}

It is important to note that the shore types in Nigeria are quite different from the ones found in some temperate countries; hence, the slight differences that may be observed in the ESI classifications in this paper.

The relative proportions of each shoreline categories reveals that sheltered vegetated low banks are the most prominent with almost $40 \%$ presence. This is perhaps an indication of the overall sensitivity of the entire area.

In table 5 the distribution of socio-economic and biological features along the shorelines are presented. This reveals the richness of each shoreline with respect to biodiversity. The table also gives insight to geographical targeting of protective or containment actions.

From the results in table 5 it appears there is a relationship between the distribution of socioeconomic features and biological productivity of the shorelines. To ascertain this, Spearman's rank correlation was used to test the level of association and the result showed a correlation coefficient (' $r$ ') value of -0.6; which by simple interpretation implies that there is an inverse relationship between socio-economic features and biological productivity.

Sometimes correlation may not imply causality; however in the case at hand it can be established that cause and effect exists between socio economic resources and biological resources.

From the species richness computation, it is obvious that shore sensitivity with respect to biodiversity distribution is only high sensitivity at a few locations such as Lagos harbour (Atlas cove side), the Mangrove vegetation along Light house creek and, Tarqua bay beach and the fringes of Light house. It is moderate along most beaches and some creek but at other locations it is either low or very low. The computed scores as guided by the rule in table 2. The reason for such pattern is not unconnected with the heavy human impact in the area.

\section{The ESI map}

Figure 3 is the composite of the information in Tables 1 and 3. The information was utilised to depict the relative shore sensitivity on the Initial ESI map. The color codes used presents the entire coastline environment according to relative sensitivity. Warm tones depict high sensitivities and cooler tones lower sensitivities. At a sight, the map presents most of the shoreline in warm colours as compared to the ones in cooler colours. The cooler tones are seen to be generally contiguous with the ocean front. The location of more sensitive shores can be identified at a glance. Human settlements located along shorelines at Tarqua Bay, Ogogoro and Tomaro were coded orange. These shores exhibits extensive vegetation that requires saturated soils for growth and reproduction they were assigned ESI 9c, while the mangrove and wetlands (assigned ESI 10a) were coded red. Bar-beach (ESI 2a) was coded purple, Tarqua bay and light house beaches (ESI 3a) coded blue and Kuramo beach (ESI 4a) was coded light blue. Although kuramo does not show much biological 
productivity perhaps because of heavy human presence it was found more sensitive based on coastal morphology. Rip Raps (ESI 6b) along the moles were coded light green.

Table 5. Biological and socioeconomic features per shore locations

\begin{tabular}{|c|c|c|c|c|}
\hline & Location & $\begin{array}{l}\text { ESI } \\
\text { type }\end{array}$ & $\begin{array}{c}\text { Number of socio } \\
\text { economic } \\
\text { features }\end{array}$ & $\begin{array}{c}\text { Number of Species of } \\
\text { biota encountered. }\end{array}$ \\
\hline 1 & Victoria island beach (Kuramo) & $4 a$ & 1 & 6 \\
\hline 2 & Victoria island (bar beach) & $2 a$ & 1 & - \\
\hline 3 & Light house beach & $3 a$ & - & 23 \\
\hline 4 & Tarqua-bay beach & $3 a$ & 1 & 6 \\
\hline 5 & East mole V/Island & $6 b$ & 1 & 25 \\
\hline 6 & East mole (Lagos harbour) & $6 b$ & - & 22 \\
\hline 7 & West mole (Lagos harbour) & $6 b$ & - & 25 \\
\hline 8 & $\begin{array}{l}\text { West mole } \\
\text { (light house beach) }\end{array}$ & $6 b$ & - & 17 \\
\hline 9 & Lagos harbour (V/Island) & $1 b$ & 9 & 5 \\
\hline 10 & Lagos harbour (Atlas cove side) & $3 a$ & 3 & 26 \\
\hline 11 & Badagri creek (water) & $10 c$ & - & 10 \\
\hline 12 & Light house creek & $10 c$ & - & 10 \\
\hline 13 & Five-cowrie creek & 10c & - & 10 \\
\hline 14 & Porto-Novo creek & $10 c$ & - & 10 \\
\hline 15 & Badagri creek fringes & $9 b$ & 2 & 17 \\
\hline 16 & Five-cowrie creek fringes & $9 b$ & & 15 \\
\hline 17 & Porto-Novo creek & $9 b$ & 5 & 21 \\
\hline 18 & Light house fringe & $9 b$ & - & 27 \\
\hline 19 & Mangrove (via Ogogoro village) & $10 a$ & - & 23 \\
\hline 20 & Mangrove (Via NNPC depot) & $10 a$ & - & 22 \\
\hline 21 & Mangrove (Tarqua bay) & $10 a$ & - & 27 \\
\hline 22 & Mangrove ( Light house crk) & $10 a$ & - & 26 \\
\hline 23 & Mangrove (Badagri crk upper) & $10 a$ & - & 22 \\
\hline 24 & Mangrove(Badagri crk) & $10 a$ & - & 27 \\
\hline 25 & Igbo Ejo swamp & $10 \mathrm{c}$ & - & 25 \\
\hline
\end{tabular}

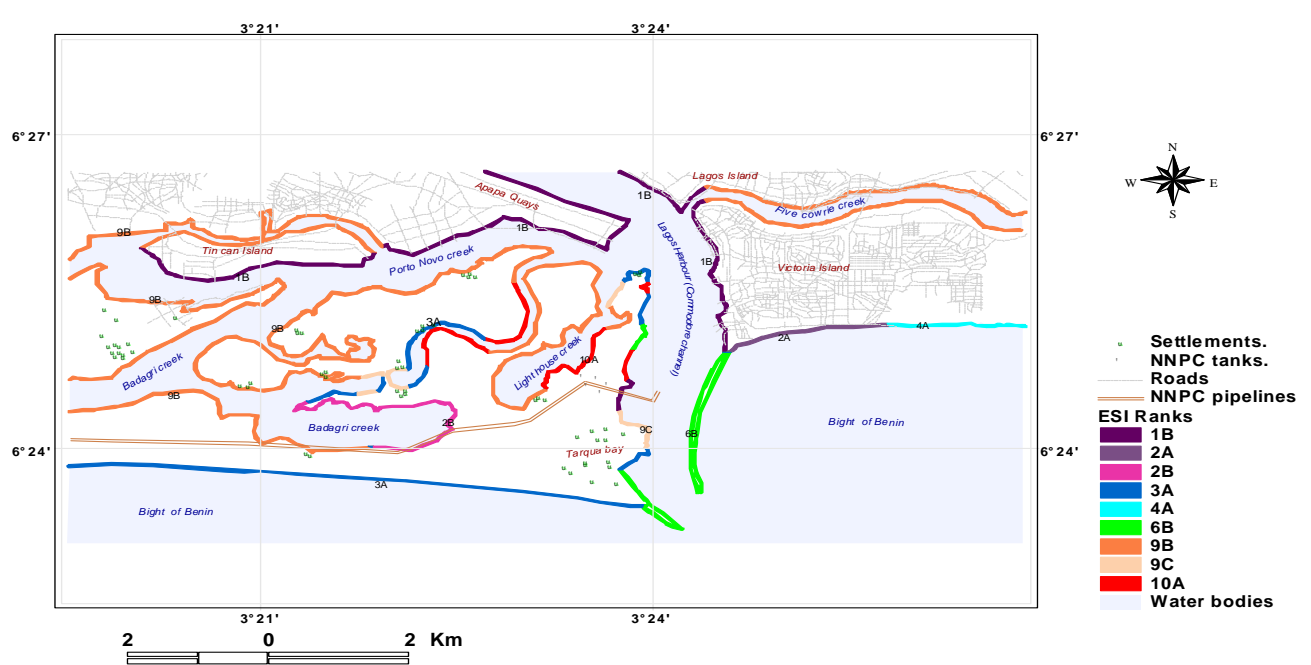

Figure 3. Shoreline sensitivity 
Table 6. Sensitivity of shoreline with respect to species richness

\begin{tabular}{|c|c|c|c|c|}
\hline Beach & $\begin{array}{l}\text { No of } \\
\text { biota }\end{array}$ & $(D a=S-1 / \log N)$ & Score & Sensitivity \\
\hline $\begin{array}{l}\text { Victoria island (bar } \\
\text { beach) }\end{array}$ & 0 & -0.165425826 & 0 & $\begin{array}{l}\text { No } \\
\text { sensitivity }\end{array}$ \\
\hline Lagos harbour (V/Island) & 5 & 0.661703306 & 3 & Very low \\
\hline $\begin{array}{l}\text { Victoria island beach } \\
\text { (Kuramo) }\end{array}$ & 6 & 0.827129132 & 3 & Very low \\
\hline Tarqua-bay beach & 6 & 0.827129132 & 3 & Very low \\
\hline Badagri creek (water) & 10 & 1.488832438 & 4 & Low \\
\hline Light house creek & 10 & 1.488832438 & 4 & Low \\
\hline Five-cowrie creek & 10 & 1.488832438 & 4 & Low \\
\hline Porto-Novo creek & 10 & 1.488832438 & 4 & Low \\
\hline Five-cowrie creek fringes & 15 & 2.31596157 & 6 & Moderate \\
\hline West mole & 17 & 2.646813223 & 6 & Moderate \\
\hline Badagri creek fringes & 17 & 2.646813223 & 6 & Moderate \\
\hline Porto-Novo creek & 21 & 3.308516529 & 6 & Moderate \\
\hline $\begin{array}{l}\text { East mole (Lagos } \\
\text { harbour) }\end{array}$ & 22 & 3.473942356 & 6 & Moderate \\
\hline $\begin{array}{l}\text { Mangrove (Via NNPC } \\
\text { depot) }\end{array}$ & 22 & 3.473942356 & 6 & Moderate \\
\hline $\begin{array}{l}\text { Mangrove (Badagri crk } \\
\text { upper) }\end{array}$ & 22 & 3.473942356 & 6 & Moderate \\
\hline Light house beach & 23 & 3.639368182 & 6 & Moderate \\
\hline $\begin{array}{l}\text { Mangrove (via Ogogoro } \\
\text { village) }\end{array}$ & 23 & 3.639368182 & 6 & Moderate \\
\hline East mole V/Island & 25 & 3.970219835 & 6 & Moderate \\
\hline $\begin{array}{l}\text { West mole (Lagos } \\
\text { harbour) }\end{array}$ & 25 & 3.970219835 & 6 & Moderate \\
\hline $\begin{array}{l}\text { Lagos harbour (Atlas } \\
\text { cove side) }\end{array}$ & 26 & 4.135645661 & 7 & High \\
\hline $\begin{array}{l}\text { Mangrove ( Light house } \\
\text { crk) }\end{array}$ & 26 & 4.135645661 & 7 & High \\
\hline Light house fringe & 27 & 4.301071488 & 7 & High \\
\hline Mangrove (Tarqua bay) & 27 & 4.301071488 & 7 & High \\
\hline Mangrove(Badagri crk) & 27 & 4.301071488 & 7 & High \\
\hline
\end{tabular}

Figure 4 is the overall ESI map which contains the positions and symbols of important features in the environment. This simply reveals the location of socio-economic features and sensitive biological resources that will be affected by oil spill.

\section{Discussions}

To distil the complexities of shorelines into biodiversity distribution pattern and proportion of shore types alone will lead to gross simplification and the underlying assessment becomes unavoidably subjective. Looking at the importance attached to individual issues in ESI mapping, it was essential to dwell on the physical attributes of each shorelines. This lent some accuracy to prediction of the behaviour of oil and possibly guided in recommending the best clean up method. A complementary profile on the physical attributes of the shorelines and relative biological productivity contains shore information that borders on coastal dynamics and sensitivity.

Impact of oil may not be so severe along the solid man-made structures since it is made of hard impregnable sea walls and pilings exposed to direct wave action. Any oil deposited on these sea walls or solid man-made structures will be rapidly removed from exposed faces, although oil persistence on any specific shoreline is related to the incoming wave energy which for most of these shore type is relatively weak compared to the ocean wave. The most resistant oil on solid man-made structures would only remain as patchy bands which can easily be recovered at or above the high water line. However to prevent leaching of the oil from the structures high pressure spraying with 
dispersant may be required to remove oil from the solid man-made structures. Clean up crews should make sure they recover all released oil.

At the bar beach in Victoria Island, any oil slick from the sea will easily get to the shore with high wave action but it is also most likely to be washed away in a short time. The situation at the Light house and Tarqua bay resort beaches will be different. Here the oil may be buried by sand within the first few weeks since they are accreting beaches. It is important to note that during small spills oil will most likely concentrate in bands along swash line of sandy beaches. Maximum penetration of oil into fine grain sand will be less than $15 \mathrm{~cm}$. While penetration into coarse grain sand can reach $25 \mathrm{~cm}$ burial of oiled layers by clean sand within the first few weeks after the spill will be limited usually to less than $30 \mathrm{~cm}$ whereas burial up to $60 \mathrm{~cm}$ on coarse grain is possible. If the oil is stranded on shore at the beginning of an accretion period, such as after a storm, the deepest burial will occur but much of the oil will be removed during the next storm. Heavy accumulations of residual oil can form tar mats. However biological impacts are likely to be low except when the beaches are being used for nesting and foraging.

However, because of the heavy recreational use of these beaches an extensive clean up efforts to remove as much of the oil as possible may be required. Victoria Island beach has a very high exposure to wave energy this could explain its eroding nature. Sand removal should therefore be kept to a minimum to avoid further erosion problems. The use of heavy equipments for oiled sediments removal of excess amount of sand therefore manual clean up may be preferable. However, mixing the oil into deeper into sediments and contamination of adjacent clean areas should be prevented. If possible cleanup crews should wait for all the oil to come offshore prior to the removal of oiled sediments.

Rip raps are generally exposed to very high wave energy. Deep penetration of oil between boulders is likely where the riprap is placed at the water line especially on the East mole on Victoria Island side of the commodore channel. Oil may readily adhere to the rough rock surfaces and if it not quickly removed, it may cause chronic leaching until the oil hardens into an asphalt deposit. When the oil is fresh and liquid, high pressure spraying and or water flooding may be effective making sure to recover all released oil. Heavy and weathered oil will be more difficult to remove. As such it may require scraping and or hot-water spraying. If the oiling is beyond was can be put under control, it may be necessary to replace heavily oiled riprap. If oil should adhere to the rough surfaces of the heavy boulders, it may result in chronic leaching until it hardens to an asphalt deposit on impermeable surfaces. Fresh oil could be removed by pressure spraying weathered oil may be more difficult to remove by ordinary pressure spraying or water flooding. It may require that water spraying scraping or even complete removal of the rip rap in case it is heavily oiled.

Sheltered vegetated low banks (ESI 9b) were found almost along the banks of all creeks colonized by terrestrial plants that grow in aerated soils occur prominently along the upper reach of creeks and their embankments. In the event of spillage, oil will adhere to any vegetation along the water line. Very heavy accumulations will be trapped along shoreline irregularities and pool in any surface depressions.

Response staff should therefore note that all free oil must be removed by vacuum or low pressure flushing. If it is necessary to remove the contaminated vegetation it should be done only when confirmed necessary and under close supervision.

The mangroves, creeks and brackish water swamp ranked highest with scores of $10 \mathrm{a}, 10 \mathrm{c}$ and $10 \mathrm{c}$ respectively, similar studies in the Niger Delta region of Nigeria (Gundlach et al., 2001) support the fact that mangroves and wetlands are about the most sensitive in terms of impact of oil spill on biodiversity in shore line. Oiling would certainly impact heavily on the area since it would be difficult to cleanse easily and several life forms would be affected. The mangroves and wetlands have low exposure to wave energy but since the slope is a gentle one, slight tidal increase will get oil on to it. Moreover, the NNPC pipeline right of way passes directly through part of the mangroves. The NNPC pipes for many points along its length have been mutilated by vandals and it is beyond mere conjecture to say it will be a big threat to the ecosystem of the entire area in the very near future. Oil would adhere to vegetation and if not quickly removed may smother then and kill the animals. Very heavy oil accumulations will be trapped in irregularities and depressions. Hence, the use of vacuum, low pressure flushing should be considered. 

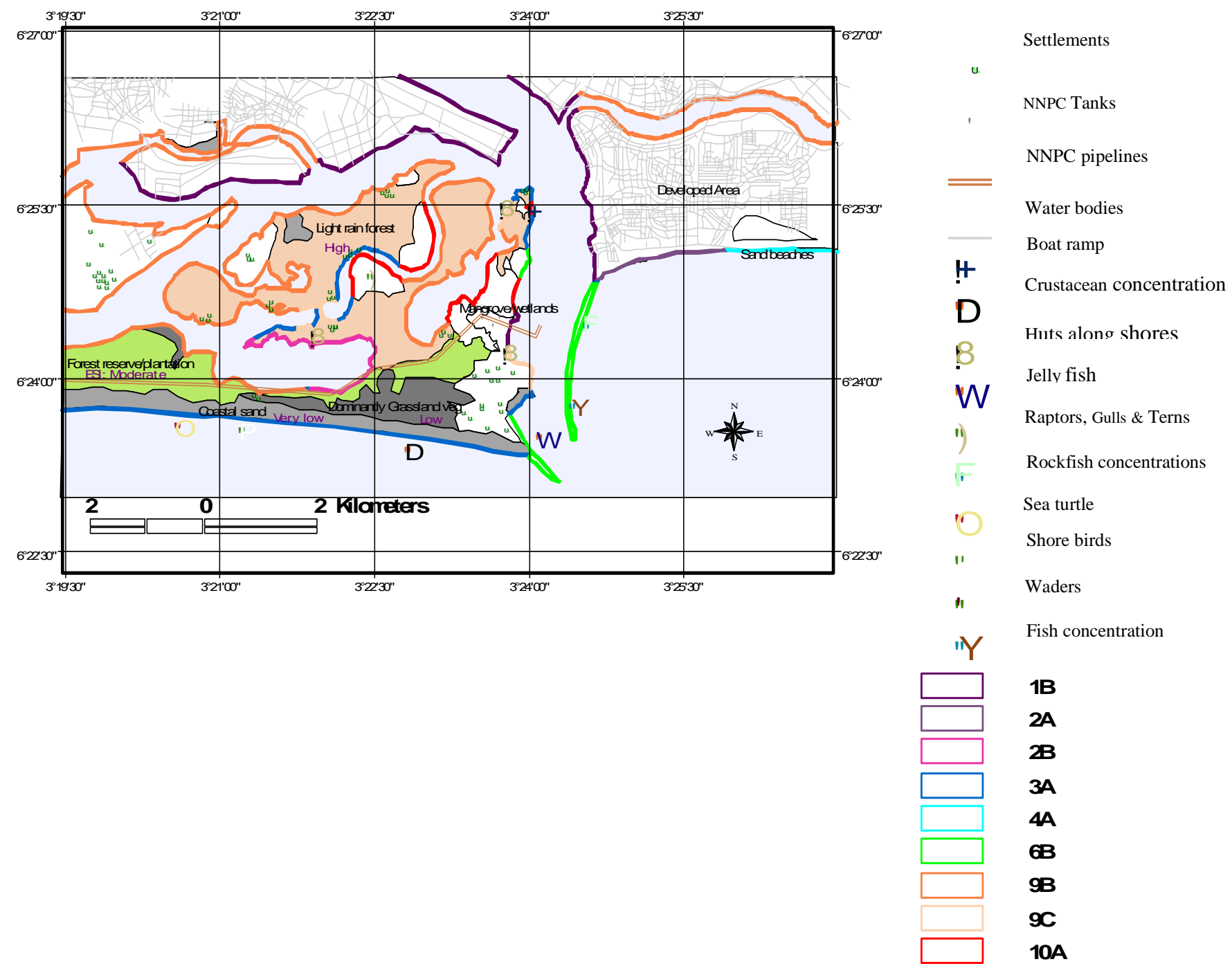

Figure 4. Over all ESI Map of Atlas cove

Where Huts, houses were found along shoreline (ESI 9C), boom should be put in place before the oil slick arrives because of the high value placed on human habitats. In cases of contamination, detergent or dispersant options should be considered.

From the ESI map for the shorelines, two ready source of oil spill pollution are depicted clearly, one is the NNPC depot that appears centrally located in the area, the other is the Ocean which could be a ready source of pollution coming from tankers accidents or drift from the off shore wells of Ondo, Ogun and Lagos state if and when they begin to mine their discovered oil deposit. With the ESI maps, distribution and the general attribute of the area can be seen at a glance; wildlife niches can be identified and easily protected. The mangroves and the most sensitive shorelines are coded with warm colours in order for field workers to know where first to protect. The wetlands ranked highest while the sandy beaches are about the lowest. The colour codes on the map generally point to the fact that the area has highly sensitive shorelines especially along the creeks.

\section{CONCLUSION}

The Environmental Sensitivity Index Mapping of Atlas cove Lagos shorelines will go a long way in improving the information and preparedness of coastline managers in their effort at protecting Nigerian shorelines from major oil or chemical disasters.

The safest means of protecting the Atlas cove shorelines from marine spill therefore is to place a boom at the entrance of the Lagos channel while curtailing the oil from getting to very sensitive areas like Kuramo end of Victoria Island beach and the light house beach respectively. Response 
agencies like National Oil Spill Detection and Response Agency (NOSDRA) and National Emergency Management Agency (NEMA), Nigerian Environmental Study Team (NEST) etc should take note of important and sensitive areas like the light house beach where shore birds do visit and rare species sea turtle chose as nesting sites

These information were the prerequisites to coastal spill managements. According to Moller et al., (2003), West Africa of which Nigeria is a prominent coastal nation, has a very low level of preparedness in combating oil pollution; with a preparedness score of minus one (-1), the level of risk by far outweighs that of preparedness.

From the findings of this study, The Atlas cove environment is definitely highly vulnerable to oil spills but beyond this, it is generally speaking, a highly sensitive environment to oil spill.

The data gathered required to be put in a seamless manner that could be managed by a robust information management system; this would guarantee update in real time and would help in decision support with respect to rapid response in the nearest future. From this study, GIS-supported Environmental Sensitivity Index mapping has proved very useful for this purpose. For a long time to come, GIS will remain one of the most important tools in contingency planning and rapid response to oil spill. The ESI maps will also sometimes find wider usage in areas such as coastal resource inventory/assessments, Environmental Risk Assessment, coastal and recreational planning, Environmental Impact Assessments and Baseline Environmental Studies.

The ecosystem's sensitivity level while still imperfectly understood has perhaps being the most critical aspect of the pollution debate. Ecological aspect of the environment need be given serious consideration in studies of this nature. The great emphasis given to the issues of species extinction and environmental resources protection appear to a large extent yet unfruitful probably because previous studies in Nigeria placed emphasis on human use/socio-economic features rather than the ecosystem as a whole. To put priority on human use resources may be important but it should be borne in mind that genes species and organisms are the product of over 3 billion years of evolution and they are the basis for the survival of the human species. Therefore, earth's resources ought not to be put in jeopardy at the instance of human socio-economic features. There is therefore the need to incorporate biodiversity into Environmental Sensitivity Indexing as shown in the present study.

\section{REFERENCES}

Egberongbe F.O.A., Nwilo P.C. and Badejo O.T. (2006), Oil Spill Disaster Monitoring Along Nigerian Coastline. TS 16 - Marine and Coastal zone Mangt - Environmental Planning Issues. (www.fig.net/pub/fig2006/papers/ts16/ts16_02_egberongbe_etal_0223.pdf).

Fabiyi O.O. (2002), Real Time Space Remote Sensing data and GIS for Oil Spill Disaster management in Nigerian Niger Delta: a call for paradigm change. Report of UN/ECA workshop on Disaster management in Africa (http/www/uneca.org Edited by David Stephens).

Gundlach E.R. and Hayes M., (1978), Classification of coastal environments in terms of potential vulnerability to oil spill damage, Marine Technology Society Journal, 12(4), 18-27.

Gundlach E.R, Hayes M.O. and Getter C.D., (1981) Sensitivity of coastal environments to oil spills. Proc. Seminar, Petroleum Industry and the Nigerian Environment, Warri, Nigeria. p. 82-88.

Gundlach E.R. and Murday M. (1987), Oil Spill Sensitivity Atlas for Mauritius. Prepared for United Nations, International Maritime Organization, U.N. Development Program, and Mauritius Ministry of Housing, Lands and the Environment, $146 \mathrm{pp}$.

Gundlach, E., V.O. Imevbore, B. Witherspoon and J. Ainodion, 2001. Incorporating biodiversity into sensitivity maps of the Niger River delta. 2001 International Oil Spill Conference, American Petroleum Institute, Wash. DC. p. 391- 403.

National Oceanic and Atmospheric Administration, NOAA (1996),. ESI Guidelines, Technical Memorandum NOS ORCA 115, 175 pp. (http://response.restoration.noaa.gov/index.html)

Nosakhare E., Fairbairn D. and Taiwo L. (2004) Mobile Handling of Environmental Sensitivity Index (ESI) Dataset. (http://www/gisig.it/coastgis/papers/erharuy.pdf) 